\title{
KONSUMENCI ANARCHII. KRYTYKA W WARUNKACH NIEPEWNOŚCI
}

Jednym z wydarzeń artystycznych, towarzyszących programowi Europejskiego Kongresu Kultury we Wrocławiu był, prezentowany w ramach projektu kuratorskiego „Trickster 2010”, performans Oskara Dawidzkiego „Przyczynek do anatomii złego smaku." Dawidzki zaprosił uczestników do udziału w wernisażu bez wystawy. W ceremoniale, który nie inaugurował żadnej artystycznej wypowiedzi, nie odsyłał nas do żadnej „sztuki dla zmiany społecznej." Formalnej i konceptualnej obróbce poddawał zaś pewien rytuał interakcyjny: dyskretny urok "artystycznej branży”, „iwent” środowiskowy, wyżerkę. A jednak tytułowy zły smak nie był prostym szyderstwem ze współczesnej okołoartystycznej socjety, z luminarzy sztuki najnowszej i jej satelitów, z salonu, w który popada w końcu każde środowisko. Nie był zatem powtórzeniem znanych z historii obydwu awangard prowokacji, skierowanych przeciw oficjalnemu „światu sztuki”, o ile trudno w dzisiejszych warunkach zapomnieć, jak szybko wywrotowe gesty normatywizują się i rytualizują, a wywrotowi prowokatorzy zasilają ostatecznie jakiś establishment (często zresztą równie chwilowy, co skierowany przeciw niemu bunt). Tym, co różniło prowokację Dawidzkiego od innych prowokacji, było subtelne zakłócenie - pomieszanie smaków. Na elegancko zaaranżowanych stołach wódka o smaku kiełbasy, czekolada cuchnąca czosnkiem i przypalone kanapki. W komentarzu do tego wydarzenia Dorota Jarecka interpretowała "podstępne” zachowanie artysty:

\footnotetext{
„Dla mnie był to komentarz na temat języka, którym mówi się dzisiaj o sztuce, a który potrafi świetnie łączyć ze sobą anarchię i komercję. Jedząc te niezbyt dobre, a jednocześnie atrakcyjne kanapki (atrakcyjne właśnie dlatego, że niedobre) staliśmy się dokładnie tym, czego od nas się w takiej sytuacji oczekuje: konsumentami anarchii. Nie wchłonęliśmy jej aż tyle, żeby zmieniać podstawy świata, ale wystarczająco, by poczuć zadowolenie z możliwości wyrażenia niezgody. Jeśli są jakieś ograniczenia sztuki krytycznej pokazywanej w ramach kongresu, Oskar Dawidzki pokazał je znakomicie" (Jarecka 2011).
} 
Interpretacja performansu Dawidzkiego i wątpliwości autorki dotyczące współczesnych roszczeń społecznej skuteczności sztuki, zgłaszanych $\mathrm{w}$ ramach takich wydarzeń jak Europejski Kongres Kultury, wpisują się dobrze $\mathrm{w}$ szerszą dyskusję na temat krytycznego potencjału działan artystycznych w ogóle, w tym zwłaszcza sztuki od lat 90. XX w., czyli po tzw. zwrocie społecznym: relacyjnej, partycypacyjnej czy zorientowanej na wspólnotę (community-specific). Główne hasło Europejskiego Kongresu Kultury, "Sztuka dla zmiany społecznej” ukierunkować miało przecież naszą uwagę na takie jej zadania, jak emancypacja, partycypacja, krytyka status quo, społeczna skuteczność i zdolność do wprowadzania zmian. W tekście badającym dylematy tak rozumianej sztuki Piotr Juskowiak wskazuje:

„Podkreślenie wagi zwrotu społecznego w sztuce stało się możliwe za sprawą rozmaitych i coraz liczniejszych w ostatnich latach wspólnotowych projektów artystycznych (określanych przez Miwon Kwon, za Christopherem Sperandio, mianem community-specific dla odróżnienia od i w nawiązaniu do dotychczasowego hegemona na gruncie sztuki publicznej - site-specific art). Niezależnie od stopnia partycypacji animowanej wspólnoty praktyki te nastawione są zwykle, przynajmniej deklaratywnie, na emancypację, (re)produkcję lokalnej tożsamości, wzmocnienie (empowerment) czy demarginalizację wykluczonych społecznie i ekonomicznie grup (mniejszości etnicznych i seksualnych, bezrobotnych, bezdomnych, osób starszych i dzieci, niepełnosprawnych)" (Juskowiak 2011: 43).

Jak sugeruje autor, jakkolwiek bliskie byłyby nam ambicje artystek i artystów, i niezależnie od tego, jak ważne są naszym zdaniem podejmowane $\mathrm{w}$ podobnych projektach społeczne kwestie, nie można stracić z pola widzenia wpisanych w nie ambiwalencji: 1) swoistej „estetyzacji problemu społecznego", o ile przeważnie efekt artystyczny oparty jest na wytworzonej przez artystę, a nie przez wspólnotę „wiedzy technicznej oraz wizji estetyki i piękna" (Juskowiak 2011: 46); 2) uszkolenienia relacji twórca-wspólnota, odległej najczęściej od Ranciere'owskiego postulatu przyjmowania przez artystę roli nauczyciela-ignoranta, a popadającej $w$ stary eurocentryczny i elitarystyczny schemat mistrz-uczeń lub, co gorsza, oświecony intelektualista vs „dobry dzikus”; 3) nierozpoznania samej kwestii międzyludzkich więzi wytwarzanych w projektach sztuki relacyjnej, przez co dochodzi „do afirmacji samego spotkania i dobrych intencji artysty w sposób dalece niesatysfakcjonujący z uwagi na kwestię miejsca danej zbiorowości w szerszych układach społecznych" (Juskowiak 2011: 43-47). Analizując z punktu widzenia tych trzech wątpliwości, dedykowany brazylijskim catadores (padlinożercom) - zbieraczom śmieci - projekt fotograficzny Pictures of Garbage Victora Muniza i towarzyszącą mu dokumentację filmową, autor odwołuje się tu zresztą do dylematów, które wobec zwrotu społecznego w sztuce artykułowały wcześniej i bardzo wyraźnie zarówno Miwon Kwon, jak 
i Claire Bishop. (Kwon 2002; Bishop 2004: 2009) Wątpliwości dotyczące rozpoznania charakteru sytuacji społecznych, inicjowanych i stawianych w centrum sztuki relacyjnej na przykład przez Nicolasa Bourriaud czy Granta Kestera (Bourriaud 2002, 2012; Kester 2004) podnosiła szczególnie ostatnia z autorek. Postulowane przez "relacjonistów” mikrotopie, kameralne sytuacje twórcze, pozwalające się artykułować wspólnocie w działaniu, niezależnie od tego, jaką formę działanie to przybiera: gotowania, fotografowania, rozmawiania, Bishop interpretuje wprawdzie jako krok w przód w stosunku do neoawangardowych programów sztuki interakcji i współtworzenia, znanych z postulatów Fluxus, z happeningów i teatru politycznego czy z interpelacji Beusa do twórczego społeczeństwa, w którym „każdy jest artystą" (Bishop 2004: 61).

O ile w pierwszym wypadku chodzić mogło jeszcze o „śmierć autora” i „otwarcie dzieła”, o sytuację komunikacyjną, wytworzoną przez sztukę, która zaprasza, angażuje i włącza "zewnętrzne" jeszcze wobec siebie społeczeństwo, o tyle w sztuce relacyjnej chodzi już raczej o to, co w efekcie tego zaproszenia wydarza się dalej - o samą więź. Postulowane przez Bourriauda odroczenie kryteriów estetycznych $\mathrm{w}$ ocenie tak rozumianej sztuki, na rzecz kryteriów etyczno-politycznych, odpowiedzialnych za szerszy, etyczny zwrot w całej okołoartystycznej praktyce (również w krytyce i refleksji teoretycznej), nie rozwiązuje jednak - zdaniem Bishop - kluczowego problemu: na jakiej podstawie mamy te relacje oceniać? Prowadzi to w efekcie do paradoksu: albo każdą sztukę deklaratywnie partycypacyjną, relacyjną i angażującą jako taką uznajemy po prostu za dobrą, albo popadamy w nieustanne tropienie rozdźwięku między deklaracjami i intencjami artystów a samymi skutkami ich projektów. O intencjach trudno jednak przesądzać, a o skutkach prorokować:

„Bourriaud zrównuje osąd estetyczny z etyczno-politycznym osądem relacji wytwarzanych w działaniu artystycznym. Ale jak mamy oszacować lub porównywać te relacje? [...] Kiedy Bourriaud twierdzi, że „spotkania są ważniejsze niż spotykające się jednostki" odnoszę wrażenie, że to pytanie jest dla niego nieistotne. Każda relacja, która umożliwia dialog jest automatycznie uznawana za "demokratyczną", a tym samym „dobrą." Ale co właściwie "demokracja” znaczy w tym kontekście? Jeśli sztuka relacyjna wytwarza relacje społeczne, to następne logicznie pytanie brzmi: jakie relacje są tu wytwarzane? Dla kogo? Po co?" (Bishop 2004: 65).

Tu dochodzimy do sedna wątpliwości Bishop. Postulat odraczania kryteriów estetycznych na rzecz etycznych, cokolwiek miałoby uprawniać nas do ich definiowania i stosowania, trwale jest wpisany $\mathrm{w}$ przepracowywaną na różne sposoby przynajmniej od Romantyzmu opozycję autonomia/zaangażowanie sztuki, od początku źle rozpoznaną jako opozycja właśnie: 
„W schemacie [sztuki relacyjnej - przyp. AS] tryumfuje samopoświęcenie: artysta powinien wyrzec się autorskiej obecności, pozwalając mówić przez siebie uczestnikom. Temu poświęceniu siebie towarzyszy idea, że sztuka powinna wydobyć się z „bezużytecznej” sfery estetyki i stopić z praktyką społeczną” (Bishop 2009: 57-58).

A jednak, jak powtarza autorka za Rancierém, autonomia i relacja to już nie dwa odrębne programy, wobec których opowiadać ma się współczesna sztuka. Jej podstawową pracą jest bowiem „myślenie sprzeczności” i wykorzystanie jej, które nie jest tym samym, co popadanie w nią. To raczej kwestionowanie podziału, ponawiane po to, aby nie wpisywać się $\mathrm{w}$ jego logikę. Mówiąc wprost - zmiana, to nie to samo, co wymiana: bezużytecznej estetyki na nieestetyczną użyteczność. Rancieré sugeruje przecież: jeśli system (polityczny, społeczny, ekonomiczny) wykorzystuje estetykę (i krytykę) do samoodtwarzania, rezygnacja sztuki z estetyki jest niczym innym, jak złożeniem broni w ręce wroga. (Ranciere 2007a, 2007b) „Wg Ranciera estetyki nie trzeba poświęcać na ołtarzu zmiany społecznej, gdyż sztuka zawiera już w sobie ową obietnicę ulepszenia" (Bishop 2009: 58).

Przywoływanie po raz kolejny powyższych kwestii, może powodować z wolna zawrót głowy, wpisany zresztą, co niewykluczone, w każde myślenie krytyczne. Doświadczamy go co najmniej od czasów odróżnienia twórcy jako wytwórcy od zaopatrującego system robotnika przemysłu kulturowego, sytuacji od spektaklu, sztuki krytycznej od estetyzacji życia, demokracji radykalnej i polityki tożsamości od postpolityki itp. Od niedawna i na lokalnym gruncie doświadczamy go zaś dzięki odróżnieniu społecznej stosowalności sztuk Żmijewskiego, od nowej autonomii, postulowanej przez tzw. nowoawangardzistów (w tym Dawidzkiego), czy sztuki zaangażowanej od angażującej, jak w Rancierowskim stylu proponował Paweł Mościcki. (Żmijewski 2007; Kurant, Dawidzki, Ronduda, Simon, Bendyk 2009; Mościcki 2008). O ile bowiem wszystkie powyższe hasła wynikają z doskonale ugruntowanej świadomości, że status quo, które chciałaby zmieniać sztuka oparte jest na jednoczesnym produkowaniu i likwidowaniu sprzeczności, największą trudność sprawia nam najwyraźniej znalezienie sposobu na to jak, rozpoznając podobną logikę, nie działać w jej obrębie. Tytułowi „konsumenci anarchii", o których wspominała Jarecka, to bowiem zarówno "na nowo" zaangażowani, jak i "na nowo" autonomiczni twórcy: krytyczni, politycznie i społecznie zorientowani artyści, aktywiści, animatorzy, kuratorzy i krytycy, którzy zdając sobie doskonale sprawę z zakusów późnego kapitalizmu do wchłonięcia społecznej skuteczności sztuki i zasymilowania krytyki, zjechali na oficjalny Kongres - środowiskową „wyżerkę”. To nie rytuały współczesnych środowisk artystycznych obrzydza Dawidzki, a ich udział w Kongresie. Kto skorzystał z jego poczęstunku pierwszego dnia wrocławskiego festiwalu społecznie zaangażowanej sztuki, do ostatniego 
z trudem pozbywał się absmaku. Spowodowanego jednak rzeczywiście wcale nie faktem, że wykwintne tartinki były ciężkostrawne, ale że takie właśnie miały być.

EKK przygotowany wspólnie przez Ministerstwo Kultury i Dziedzictwa Narodowego oraz Narodowy Instytut Audiowizualny traktowany był od początku jako główne wydarzenie polskiej prezydencji w UE. W tym sensie było to oficjalne forum polityczne o międzynarodowym rezonansie, poświęcone problemom współczesnej europejskiej polityki kulturalnej, o czym świadczy obecność zarówno ministrów kultury poszczególnych państw czy polskich polityków odpowiedzialnych za politykę kulturalną i społeczną (Michał Boni, co mniej oczywiste oraz Bogdan Zdrojewski, co oczywiste), ale także na przykład przewodniczącego PE Jerzego Buzka czy Komisarza Europejskiego ds. Edukacji i Kultury, Andrulli Vasilliu. Programowi otwartych debat intelektualistów i artystów towarzyszyły zatem także oficjalne, zamknięte spotkania polityków, odpowiedzialnych za kształtowanie polityki kulturalnej i społecznej $\mathrm{w}$ krajach Unii na najbliższe lata. Jednym z wątków Kongresu, o którym na oficjalnej inauguracji Dyrektor NInA, Michał Merczyński mówił, iż opiera się na czterech filarach: politycznym, intelektualnym, obywatelskim i artystycznym, była zatem kwestia miejsca działalności kulturalnej, w tym artystycznej, w aktualnej sytuacji społecznej, ekonomicznej i politycznej krajów europejskich. Najpełniejszy wyraz ten wymiar Kongresu zyskał w przemówieniach polityków na oficjalnej inauguracji i zakończeniu, których analizę przedstawiam w innym miejscu (Skórzyńska 2011).

Dwie cechy politycznego filaru Kongresu zwracają przy tym szczególną uwagę. Po pierwsze, to swoisty „kurs na kulturę" w polityce państw i polityce europejskiej, który można umownie nazwać programem na czas kryzysu i gwarancją solidarności w warunkach niepewnej sytuacji ekonomicznej. Mieliśmy zatem do czynienia z prezentacją programu ideologicznego (kultura jest tym, co Europejczyków łączyło od zawsze), o którym na marginesie europejskiej polityki kulturalnej ostatnich lat pisał Raimund Minichbauer (Minichbauer 2011). Po drugie to dominująca $w$ oficjalnych wypowiedziach ekonomistyczna wizja kultury, obecna w odwołaniach polityków do takich kategorii jak rozwój kreatywny, społeczeństwo wiedzy, przemysły kreatywne itp., które pokazywały wyraźnie, iż akcent położony na potencjał tzw. niematerialnych czynników rozwojowych w czasach kryzysu, wpisuje dzisiejszą europejską dyskusję na temat kultury i zmiany społecznej w krytykowany przecież coraz intensywniej dyskurs kreatywności czy tzw. estetyczny model produkcji, prowadzący do ekonomizacji twórczości i wiedzy (Raunig, Ray, Wuggenig 2011; Lind, Minichbauer 2009; Chmielewska, Szreder, Żukowski 2009). 
Kongres był jednak także festiwalem sztuki, umożliwiającym zarówno promocję polskiej sztuki za granicą, jak i środowiskowe spotkanie twórców z Polski i Europy - branżowe święto. Głównymi adresatami wydarzenia stali się jednak nie twórcy czy odbiorcy sztuki, ale kuratorzy, organizatorzy, animatorzy kultury. Na program artystyczny składały się projekty kuratorskie: wspomniany już Trickster 2010, wystawa 10x10 i szereg wydarzeń zgłaszanych do głównego programu konkursowego Art for Social Change. Nie ulega wątpliwości, że jako festiwal sztuki, EKK był wydarzeniem wielowątkowym, obejmującym spektakularne i bardzo efektywne promocyjnie imprezy (koncerty Krzysztofa Pendereckiego z Johnnym Greenwoodem i Aphex Twin'em), skromniejsze, choć niezwykle wymowne projekty konkretnych artystów (jak wspomniany performans Dawidzkiego czy surowa, ale wstrząsająca instalacja Mirosława Bałki) oraz wiele kameralnych działań aktywistów i artystów (projekt Krytyki Politycznej A House of Change, projekt formatowanej sztuki krytycznej Emergency Room, projekt prezentacji NGO's PechaKucha i Wyprzedaż, projekt spotkań dyskusyjnych Lunch z... czy w końcu mało udany projekt warsztatowy dla młodych artystów Reverse Pedagogy).

Niezwykle mocno promowany i podkreślany wielokrotnie był krytyczny wymiar Kongresu. W tym sensie stanowić miał on otwarte, obywatelskie forum dyskusyjne dla artystów, intelektualistów, aktywistów. Przejawem krytycznego charakteru EKK miał być program głównych debat z udziałem europejskich intelektualistów i artystów, również tych, znanych z odwołań do współczesnych odmian teorii krytycznych lub z praktykowania sztuki krytycznej, jak Chantall Mouffe, Gayatri Chakravorty Spivak, Dejan Ilic, Tomislav Medak, Pekka Himanen, Dietrch Diedrichsen, Krzysztof Wodiczko, Zbigniew Libera i in. Program panelowy był przy tym rzeczywiście ukierunkowany na najważniejsze dylematy, wynikające z relacji między kulturą/sztuką/twórczością a działaniem politycznym, sferą publiczną czy rynkiem: od problemów związanych z publicznym wsparciem/instytucjonalną kontrolą twórczości, przez kryzys współczesnej sfery publicznej i jej depolityzację (debata: „Niebezpieczne związki. Władza i kultura”), konkurujące stanowiska na temat dostępu do wiedzy i kwestii praw autorskich (debaty: „Bajki robotów” i „Masa Kultury”), ekonomiczne podstawy działalności kulturalnej i związki sztuki z biznesem (debata: „Spółka kultura. Ekonomia i kultura"), aż po dehierarchizację i popularyzację kultury z jednej strony (debata: "Zagubieni w Kulturze. Interdyscyplinarność") i odradzanie się rozmaitych odmian kulturowych fundamentalizmów z drugiej (debata: „Obca Europa”).

W gorącym komentarzu prasowym Roman Pawłowski sugerował pęknięcie, jakie towarzyszyło programowi debat, polegające na nieustannym 
konkurowaniu ze sobą dwóch wizji kultury: ekonomicznej i obywatelskiej (Pawłowski, 2011). Takie ujęcie sprawy sugerowałoby jednak, iż mieliśmy do czynienia we Wrocławiu z wydarzeniem, które przyczyniło się do ujawnienia i rozpoznania dominującej $\mathrm{w}$ warunkach hegemonii neoliberalnej demokracji i kapitalizmu opartego na wiedzy sprzeczności: między instrumentalizowaniem twórczości przez ekonomistyczno-biurokratyczną wizję rozwoju kreatywnego a działaniem twórczym, pojętym jako udział w debacie publicznej, gwarantującym jej krytyczny i demokratyczny przebieg $\mathrm{w}$ ramach tyleż zantagonizowanej sfery publicznej, co po prostu domeny wspólnej, które w odwołaniu do koncepcji własnej i Laclaua oraz Negri'ego i Hardt'a przypominała w trakcie dyskusji Mouffe. Sprawa jest jednak bardziej skomplikowana. Trudno uniknąć bowiem wrażenia, że zrekonstruowane przeze mnie powyżej trzy podstawowe wymiary EKK: polityczny, artystyczny i krytyczny były niewspółmierne.

Dyskursywnej i sytuacyjnej ramy temu wydarzeniu dostarczały oficjalne wypowiedzi polityków, dla których krytyczny spór artystów i intelektualistów stanowił rodzaj „wypełniacza”, nie wpływającego w żaden sposób na orientację lokalnej i europejskiej polityki kulturalnej. Okazał się za to bardzo efektywny promocyjnie - jak tytułowe hasło Art for Social Change. Krytyka została dopuszczona do głosu, ale raczej w roli niesmacznej zakąski, serwowanej do oficjalnego projektu politycznego, obwieszczonego na otwarciu i zakończeniu Kongresu niemalże w trybie tautologii. Jak gorzka puenta wszelkich krytycznych ambicji artystów zorientowanych na działania wspólnotowe lub interwencyjne, zabrzmiała jedna $\mathrm{z}$ pokongresowych rekomendacji, odczytana na oficjalnym zakończeniu przez Bogdana Zdrojewskiego:

„[...] Sztuka nie musi być krytyczna. Zadaniem sztuki jest oczywiście krytycyzm, [...] dobrze, jak sztuka jest krytyczna, to jest fakt, natomiast ważne jest, aby nie budować zadania dla sztuki, dla obszaru aktywności w kulturze z samego krytycyzmu, bo jest to droga niewłaściwa, albo droga budująca zadanie, które nie do końca jest prawidłowo zdefiniowane" (Zdrojewski 2011).

Co do „właściwej drogi” w oficjalnych kongresowych wypowiedziach polityków nie pozostawiono w zasadzie poważniejszych wątpliwości:

"[...] gospodarka światowa zmienia się niezwykle szybko, [w związku] z procesem digitalizacji i globalizacji, od uwagi skupiającej się na czynnikach namacalnych przenosimy uwagę na to, co nienamacalne [...] Niestety jak wszyscy wiemy kryzys finansowy odczuwany jest we wszystkich aspektach naszego życia, to wszystko wymaga myślenia kreatywnego[...] Kultura i sztuka mogą bardzo wiele wnieść do życia społecznego i gospodarki, mogą być katalizatorem innowacji.[...] dzisiaj bogactwo narodów zależne jest od wiedzy i innowacji, podkreśla to strategia »Europa 
2020 «...] Jestem głęboko przekonana, że kultura może wnieść ogromny wkład w konkurencyjność i integralność Europy,[...] może pomóc Europie w załagodzeniu i pokonaniu wyzwań społecznych i ekonomicznych, przed jakimi stoimy" (Vassiliu 2011).

Problem, o którym tu mowa niemal od początku rozpoznawany na gruncie teorii krytycznej, dziś podnoszony jest coraz mocniej przez jej współczesne odmiany, na przykład studia kulturowe. Chodzi o zdolność dominujących, hegemonicznych dyskursów do wchłonięcia zarówno języka, jak i sposobów myślenia i działania krytycznego, przejęcia oporu i wykorzystania go we własnej sprawie. Tę cechę tzw. nowego, kulturowego czy fajnego kapitalizmu (cool capitalism) (McGuigan 2009: 2010) do przejmowania niemal natychmiast form kulturowych, znanych ze współczesnych praktyk oporu dostrzegają badacze analizujący zarówno współczesny dyskurs kreatywności, jak i ekonomizację kultury w ogóle, a Jim McGuigan charakteryzuje ją następująco:

„W czasach, kiedy globalne wpływy kapitalizmu są tak silne i ekstensywne, jak nigdy dotąd, zaczynają stanowić wyzwanie. Publiczne oblicze kapitalizmu zmieniło się jednak w stosunku do jego wcześniejszej i, jak mogą twierdzić niektórzy, oryginalnej formy, [opartej na - przyp. A. S.] protestanckim ascetyzmie w bardziej hedonistyczną, „fajną" postać. „Fajny kapitalizm” rozumiem jako inkorporację przejawów niezadowolenia społecznego do samego systemu, co powoduje, że znaturalizowany opór przyczynia się właściwie do jego reprodukcji. To najbardziej żywotna cecha współczesnej kapitalistycznej hegemonii" (McGuigan 2010: 129).

W ramach większego projektu, realizowanego pod hasłem Critique of Creativity, Gene Ray proponuje na przykład reinterpretację koncepcji przemysłu kulturowego Horkheimera i Adorno już przez pryzmat filozofii poststrukturalistycznych, w tym Foucaulta, pokazując w jaki sposób zmierzające do dominacji systemy i dyskursy wytwarzają również podmioty krytyczne (Ray 2011). Niezbędne, ponieważ każda całkowita dominacja oznacza domknięcie i samopodważenie systemu - rozwiązanie totalitarne. A przecież o nowym kapitalizmie rzeczywiście coraz częściej mówimy i myślimy: "kulturowy”, "miękki”, „fajny”. Wątek systemu, który wchłania krytykę jest jednak doskonale rozpoznany, zdecydowanie gorzej z odpowiedzią na pytanie o dalsze losy postawy krytycznej.

W odniesieniu do praktyki artystycznej instruktywne są tutaj wątpliwości Bishop i Juskowiaka, dotyczące kryteriów oceny sztuki zorientowanej na wspólnotę i zmianę jej kondycji. Źle rozpoznane przeciwstawienie między kryteriami estetycznymi i etyczno-politycznymi, rzeczywiście deleguje odpowiedzialność twórców ze skutków na intencje. Zadeklarowana potrzeba „zmiany społecznej” w zupełności wówczas wystarcza, sama zbiorowość, 
w obrębie której wytwarza się relacje, ale także środki użyte do ich wytwarzania pozostają drugorzędne. Czystą „intencję krytyczną" odnajdujemy na przykład w jednym z Kongresowych projektów kuratorskich Emergency Room, charakteryzowanym przez inicjatorów jako "formatowana" sztuka krytyczna. Projekt ten polegał za zainstalowaniu tymczasowego, plastikowego obiektu-kontenera, w którym zaproszeni artyści umieszczać mieli aktualizowane $\mathrm{w}$ ciągu jednego dnia pracy komentarze do bieżących wydarzeń (ekspozycję uzupełniano każdego dnia w godzinach popołudniowych.) W efekcie powstało mini-biennale sztuki, plastikowy kontener wypełniał się bowiem dzień po dniu pracami o różnych własnościach wizualnych, wykonanymi w różnych technikach i dedykowanymi różnym problemom: od światowych i polskich wydarzeń medialnych po wydarzenia Kongresowe.

Choć wiele z prezentowanych tu „doraźnych” instalacji uznać można za bardzo ciekawe, trudno było uniknąć wrażenia, że Emergency Room stał się śmietnikiem opinii. Jedynym, co łączyło prace była ich intencja: „krytyka dla krytyki" odseparowana od problemów, „metoda” wyabstrahowana od tego, co jest jej przedmiotem i nie wiadomo do kogo właściwie adresowana. Podobne wątpliwości budzić musi zresztą tytułowe hasło kongresu „Sztuka dla zmiany społecznej" i zapraszanie na interdyscyplinarny festiwal sztuki artystów, których wspólnym mianownikiem ma być właśnie intencja krytyczna. Ciekawe zresztą, że podobne zarzuty stawia się dziś wobec dyskursu kreatywności: estetyczny sposób produkcji w przemysłach kreatywnych np. przez Marion Van Osten interpretowany jest jako poźnokapitalistyczna wersja nowoczesnej alienacji, skoro kreatywność to nic innego jak twórczość oderwana od tego, czego/kogo ma dotyczyć - pusta umiejętność (van Osten 2011: 135). Kiedy mówimy o „sztuce dla zmiany społecznej”, zarówno twórczość, jak i jej krytyczny potencjał traktujemy być może właśnie jako pustą umiejętność (lub atrakcyjne hasło promocyjne) tak długo, jak długo nie udzielimy odpowiedzi na pytanie, o jaką zmianę nam chodzi? Tu właśnie pojawia się problem afirmacji samego spotkania lub samej krytyki, bez rozpoznania szerszych układów społecznych, w których funkcjonuje określona zbiorowość (lub zachodzić ma krytyka).

Problem postawy krytycznej w praktyce artystycznej i badawczej, który dziś wydaje się wyjątkowo aktualny, ukierunkowuje na dwie podstawowe tradycje: teorii krytycznej z jednej strony oraz sztuki, realizowanej od czasów obydwu awangard w ramach rozmaitych "estetyk oporu” $\mathrm{z}$ drugiej. Współcześnie postulaty krytycznego zaangażowania odnajdujemy w wielu odmianach na gruncie praktyki badawczej i artystycznej, do tego stopnia, iż w języku angielskim używa się już liczby mnogiej: "teorie krytyczne”, w odniesieniu przede wszystkim do takich perspektyw, jak studia femini- 
styczne i studia queer, studia postkolonialne, studia kulturowe, różne odmiany współczesnego marksizmu, studia performatywne oraz takie metody badawcze, jak na przykład krytyczna analiza dyskursu (Reinelt, Roach 2007; Kincheloe, McLaren 2010). Szczególnie ciekawa jest tutaj kariera myślenia krytycznego na gruncie studiów kulturowych, które jako orientacja intelektualna zasadniczo wywodzi się z dwóch fal krytyki właśnie: teorii krytycznej w sensie właściwym (czyli frankfurckiej) oraz krytyki elitaryzmu frankfurckiego, zgłoszonej najpierw w postaci materializmu kulturowego Raymonda Williamsa i jego propozycji badań nad „zwyczajną kulturą”, a później modelu kodowania-dekodowania Halla (McGuigan 2010, Barker 2005).

To na gruncie studiów kulturowych jednak McGuigan czy Barker diagnozują od pewnego czasu przeciwskuteczność zgłaszanej w ich ramach krytyki, wynikającą z kulturowego populizmu, a więc przeceniania wywrotowego potencjału popularnych praktyk i popadania w hurraoptymizm, np. przez takich badaczy jak John Fiske, co powoduje, że koncepcje podobne do jego "suwerenności konsumenckiej” przyczyniają się w gruncie rzeczy do podtrzymania kapitalizmu konsumpcyjnego (McGuigan 1992: 70-75). Drugi zarzut dotyczy inspiracji studiów kulturowych poststrukturalizmem, skutkującej „redukcjonizmem tekstowym” - angażowaniem się w nadprodukcje analiz popularnych tekstów kultury w zamian angażowania się $\mathrm{w}$ badanie praktyk kulturowych i warunków, w których zachodzą oraz zrównywanie ze sobą odmiennych form kulturowych i odmiennych sposobów ich używania i wytwarzania, pod wspólnym hasłem badania "tekstów kultury". Jim McGuigan postuluje $\mathrm{w}$ tym kontekście uprawianie nowej, zorientowanej krytycznie analizy kulturowej, którą charakteryzuje następująco:

„Wielokierunkowa analiza kulturowa staje się dziś konieczna w związku a ontologiczną złożonością współczesnych zjawisk - to znaczy - z ich wieloaspektowością. Dotyczy obiegu kulturowego i interakcji między produkowaniem i konsumowaniem, włączając $\mathrm{w}$ to wszystkie, materialne i semiotyczne własności form kulturowych. Otwiera się na niemal nieskończoną ilość wątków, z których żaden nie jest pozbawiony znaczenia. Zasadnicze decyzje muszą być jednak podjęte, a wybory dokonane, dlatego kwestia interesu publicznego jest w tym podejściu centralna" (McGuigan 2010: 1).

Z podobnych przesłanek wyrastają także postulaty ponownego zaangażowania badaczy i krytyków kultury w politykę kulturalną lub wręcz powrotu do badań kulturowych w kategoriach ekonomii politycznej, odniesionych już jednak do neoliberalnych okoliczności.

Niezależnie od nasilających się pytań o faktyczny potencjał krytyczny studiów kulturowych, kryzys współczesnych teorii krytycznych, wiązany 
właśnie z poststrukturalizmem, wskazywał na przykład Bruno Latour (Latour 2004). Nieco histeryczne w tonie były przy tym jego wątpliwości, zgłaszane na marginesie komentarzy Baudrillarda do wydarzeń z 11 września, o ile autor nie mógł uwierzyć, że jest prawdopodobnie jednym z niewielu, którzy dostrzegają, że samoloty terrorystów naprawdę uderzyły w WTC. Były aktem terroru, a nie symulacją. Latour bierze na warsztat takie współczesne odmiany teorii krytycznych, jak analiza dyskursów, nie ulega jednak wątpliwości, że negatywnym punktem odniesienia jest dla niego cały filozoficzny poststrukturalizm, który posądza o rozmycie i zahamowanie teorii krytycznej. Ulubiony schemat myślenia krytycznego: fakty przeciw mitom, prawdziwa świadomość przeciw fałszywej świadomości popada w paradoks (i rodzaj błędnego koła), kiedy fetyszyzowaną przez krytyka sferą tego, co faktyczne są jego własne założenia dotyczące skonstruowanego charakteru stosunków społecznych (na przykład jako wyłącznie dyskursywnych, albo w całości zapośredniczonych lub zastąpionych obrazami).

Umysł krytyczny, zakładający, iż poznanie wytwarza badaną rzeczywistość, ale jednocześnie sam jest przez nią wytwarzany (co wiemy już doskonale przynajmniej od czasów przeciwstawienia przez Horkheimera teorii krytycznej teoriom tradycyjnym), wydaje się rejterować $w$ warunkach, w których nie dostrzega, że myślenie wyłącznie w kategoriach dyskursywnych czy obrazowych o rzeczywistości społecznej jest także produktem czasów i układów społecznych, w których żyje badacz (Horkheimer 2002). Zamiast wykonywać konkretną pracę krytyczną, poprzestaje na demaskowaniu ideologicznych podstaw cudzych przekonań - niczym źle działająca maszyna myśląca wypuszcza dokładnie tyle samo informacji ile otrzymuje, tyle że przetłumaczonych na inny język ${ }^{1}$ (Latour 2004: 247).

Skutek jest taki, że o ile po postrstrukturalizmie mało kto chce twierdzić, że zjawiska społeczne są kwestią faktów, a nie dyskursów, obrazów, performansów czy tekstów, o tyle te ostatnie zaczyna się traktować niemal jak „obiektywne fakty", popadając w schemat krytyczny: Mój prawdziwy język przeciw Twojemu fałszywemu. B. Latour postuluje w tym miejscu przejście od postawy krytycznej opartej na logice matters of fact, ku logice matters of concern i poszerzanie dostępnego języka krytyki (jako narzędzia postrzegania i badania tego, co społeczne) o nowe pojęcia i metafory, wynikające $\mathrm{z}$ zaangażowania umysłu krytycznego $\mathrm{w}$ badany świat i tropienia zachodzących w jego obrębie nowych splotów okoliczności i powiązań (Latour 2004). Nie kwestionuje przy tym, jak się wydaje, fundamentalnego założenia Horkheimera i całej teorii krytycznej, że poznanie i jego narzędzia są produktem społeczno-historycznym, ponieważ jest nim również umysł

${ }^{1}$ Autor, jako metaforę, przywołuje tu koncepcję maszyny myślacej A. M. Turinga. 
krytyczny, sugeruje jednak, że skoro zmieniają się społeczno-historyczne warunki kształtujące poznanie, powinien także zmieniać się stale język i procedury postępowania krytycznego - należy na przykład wybrnąć poza to, co o skonstruowanej rzeczywistości społecznej już się wie, zamiast mnożyć kolejne argumenty na temat takiego właśnie, skonstruowanego jej charakteru. Postulowane przez współtwórcę ANT śledzenie asocjacji, podążanie za aktorami, myślenie relacyjne, stale ponawiana procedura rejestrowania nowych powiązań zachodzących między różnymi, materialnymi i niematerialnymi czynnikami, posiadającymi sprawstwo w przestrzeni społecznej, jest właśnie propozycją takiej procedury krytycznej (Latour 2009, 2010).

Myślenie dialektyczne, proponowane $\mathrm{w}$ teorii krytycznej to o tyle za mało, że nie zachodzą dziś prawdopodobnie podziały, w obrębie których dialektyczny umysł mógłby się jeszcze poruszać, tropiąc podstawowe sprzeczności kapitalizmu: na bazę i nadbudowę, byt i świadomość, ekonomię i kulturę, estetykę i politykę, autonomię i zaangażowanie, sztukę i rzeczywistość społeczną, status quo i zmianę. Jeśli prawdą jest stwierdzenie Lasha i Lury „że kulturowa nadbudowa rozpadła się dzisiaj w materialnej bazie", to te opozycje nie mają sensu, a umysł krytyczny badać musi relacje na dużo wyższym poziomie złożoności (Lash, Lury 2005, 2011). Zekonomizowana kultura generuje na przykład nowe podziały społeczne, które w odniesieniu do wizji kreatywnego rozwoju i społeczeństwa kognitywnego wiązane są przeważnie z kategorią niepewności (precarity, precarization). Estetyczny model produkcji, wymagający bycia twórczym już rzeczywiście od każdego, wzmaga konieczność funkcjonowania w warunkach permanentnych zmian, kulturowych i ekonomicznych, stałe oferowanie zdolności do uczenia się i tworzenia w oczekiwaniu na, przeważnie odroczoną, gratyfikację.

Nie chcę uprzywilejowywać w tym miejscu autorskiej propozycji Latoura, ponieważ jej rzetelne omówienie i krytyka znacznie przekraczają ramy tego tekstu i, bez wątpienia również, moich możliwości. Chodzi raczej o powody kryzysu myślenia krytycznego, wskazywane przez autora: wycofanie się umysłu krytycznego z badania relacji, w które jest uwikłany jest także prawdopodobnie źródłem zgłaszanych tu wątpliwości, dotyczących krytycznego wymiaru EKK. Nie chodzi tu po prostu o to, że oficjalny dyskurs polityczny przechwycił dyskurs praktyki artystycznej czy teorii społecznej i użył jako hasła promocyjnego. Nie chodzi też tylko o język, w którym mówi się o współczesnej sztuce, jak sugerowała Jarecka, a którego nie ma już prawie bez takich haseł jak zmiana społeczna, przestrzeń publiczna, polityczność, krytyka, stosowalność i skuteczność itp. Chodzi o całkowity brak rozpoznania "szerszych układów społecznych", w których funkcjonuje dzisiaj współczesna praktyka teoretyczna i artystyczna, a które sprowadzo- 
ne zostały na Kongresie do dawno nieobowiązujących opozycji: władza i kultura, ekonomia i kultura, technologia i kultura, sztuka i zmiana społeczna itp.

Sama krytyka zaś sprowadziła się ostatecznie do tropienia sprzeczności, które prawdopodobnie wcale nie zachodzą. Jeśli zakładamy istotną rolę kultury/sztuki w budowaniu nowej, konkurencyjnej gospodarki opartej na wiedzy i przezwyciężaniu kryzysu, jakie sprzeczności władzy i kultury czy ekonomii i kultury chcemy tu jeszcze wytropić? Jeśli za jeden z podstawowych mechanizmów dominującego współcześnie systemu ekonomicznego uznajemy jego zdolność do permanentnego generowania zmian, za jedną z głównych cech późnej nowoczesności płynność, a za podstawową kondycję kreatywnego podmiotu - niepewność, jakie dodatkowe zmiany chcemy wprowadzać za pomocą sztuki i po co? Współczesny nowy, kulturowy, kognitywny kapitalizm wchłonął już dawno estetyczny model produkcji bazuje na myśleniu twórczym, również krytycznym, które jest prawdopodobnie podstawą wszelkiej twórczości. Starcie kultury zekonomizowanej z kulturą obywatelską, które zarejestrował Pawłowski, o tyle we Wrocławiu nie mogło zachodzić, o ile granica między tymi dwiema wizjami kultury bardzo trudna jest dziś do zlokalizowania. Po której ze stron tego podziału sytuują się dziś na przykład twórcy działający w ramach NGO's, pracujący od projektu do projektu w zgodzie z priorytetami programów finansowania publicznego lub wymaganiami prywatnych sponsorów?

Co zastanawiające jednak, w wypowiedziach polityków na Kongresie o deklaratywnie krytycznym charakterze prawie w ogóle nie podjęto wątków związanych na przykład z warunkami ekonomicznymi, socjalnymi czy formalno-prawnymi pracy twórczej. Na oficjalnym podsumowaniu Kongresu, na którym deklarowano ogromną rolę artystów i intelektualistów w projekcie integracji i rozwoju ekonomicznego krajów europejskich, prawie w ogóle nie podjęto problemu sytuacji tego środowiska, wynikającej na przykład z ekonomizacji kultury. Wiele uwagi poświęcono kuratorom, animatorom, aktywistom, z pola widzenia zniknęli zaś nieco twórcy i odbiorcy sztuki. Nie sposób jednak z Kongresowych wypowiedzi polityków wywnioskować, na czym polega to specyficzne przetasowanie, wymiana głównych aktorów w polu produkcji kulturowej/artystycznej i czemu ma służyć? Meandry i społeczno-ekonomiczne konsekwencje estetycznego modelu produkcji nie zostały nawet zasygnalizowane, mimo że na Kongres zaproszono środowiska, na które składają się zarówno jego beneficjenci, jak i ofiary.

Problem jednak leży nie tyle po stronie sytemu, który wchłania krytykę, ile także po stronie krytyki, która nie rozpoznaje sytemu - nie tropi układów społecznych, w których funkcjonuje, nie szuka nowego języka, nowych 
metafor i nowych form myślenia, poprzestając na intencji krytycznej oraz na powoływaniu do życia mikrotopii, w które rozpadają się dziś dawne utopie lewicowych awangard. W efekcie otrzymujemy skrawkową sztukę krytyczną, doraźne komentarze doraźnych sytuacji, emergency room. Dlatego zachowanie Dawidzkiego wydaje się podstępne. Nie wypowiadał się w niczyjej sprawie. Nie upominał o żadne wspólnoty, grupy marginalizowane, wykluczone podmioty. Nie zrezygnował też z procedury formalnej i estetycznej, wręcz przeciwnie: zaprosił nas do udziału w skrajnie estetyzowanej sytuacji. Dość dobrze jednak rozpoznał warunki, w których miał działać, przez co pozostał do pewnego stopnia krytyczny: pozostał przynajmniej krytycznym artystą zaproszonym na oficjalny Kongres.

\section{BIBLIOGRAFIA}

Barker C. (2005), Studia kulturowe. Teoria i praktyka, Wydawnictwo Uniwersytetu Jagiellońskiego, Kraków

Bishop C. (2004), Antagonism and Relational Aesthetics, "October”, issue 110 (Fall)

Bishop C. (2009), Zwrot społeczny: wspótpraca jako źródto cierpień, [w:] Stadion X. Miejsce, którego nie było. Reader, red. J. Warsza, korporacja ha!art, Kraków

Bourriaud N. (2002), Relational Aesthetics, trans. S. Pleasance, F. Woods, Les presses du réel, Paris

Bourriaud N. (2012), Estetyka relacyjna, przeł. Ł. Białkowski, MOCAK, Kraków

Chmielewska K., Szreder K., Żukowski T., (red. - 2009), Czytanki dla robotników sztuki. Zeszyt 1: Kultura nie dla zysku, Wolny Uniwersytet Warszawy, Wydawnictwo Fundacji Bęc Zmiana, Warszawa, tekst dostępny też na stronie: http://www.wuw 2009.pl/czytankid.php

Horkheimer M. (2002), Traditional and Critical Theory, [w:] M. Horkheimer, Critical Theory. Selected Essays, The Continuum Publishing Company, New York, s. 188-243

Jarecka D. (2011), Konsumenci anarchii, [w:],"Gazeta Wyborcza” - wydanie internetowe, tekst dostępny na stronie: http://wyborcza.pl/1,75475,10263227,Konsumenci_ anarchii.html [dostęp: 13.11.11]

Juskowiak P. (2011), Sztuka wspótpracy w dobie kapitalizmu kognitywnego - estetyzacja, edukacja, relacja, [w:] "Zeszyty Artystyczne” nr 21, Poznań; (korzystam z rękopisu, poszerzonego w stosunku do opublikowanego tekstu, udostępnionego przez autora, numery stron odnoszą się do wersji opublikowanej)

Kester G.H. (2004), Conversation Pieces. Community + Communication in Modern Art, University of California Press, Berkeley-Los Angeles

Kincheloe J.L., McLaren P. (2010), Teoria krytyczna i badania jakościowe. Rewizja, przeł. P. Pluciński, [w:] Metody badań jakościowych, red. N.K. Denzin, Y.S. Lincoln, red. wydania polskiego K. Podemski, Wydawnictwo Naukowe PWN Warszawa, T 1, s. 431-485

Kwon M. (2002), One Place after Another: Site-Specific Art and Locational Identity, The Mit Press: Cambridge Massachussets - London

Kurant A., Dawidzki O., Ronduda Ł.,Simon J., Bendyk E. (2009), Manifest Nooawangardy. Nowa autonomia sztuki, tekst dostępny na stronie: http://www.obieg.pl/ wydarzenie/13677 [dostęp: 13.11.11] 
Lash S., Lury C. (2005), Global Culture Industry: The Mediation of Things, Polity, Cambridge

Lash S. Lury C. (2011), Globalny przemyst kulturowy. Mediacja rzeczy, Wydawnictwo Uniwersytetu Jagiellońskiego, Kraków

Latour B. (2004), Why Has Critique Run out of Steam? From Matters of Fact to Matters of Concern, [w:] "Critical Inquiry", nr 30 (Winter 2004), The University of Chicago

Latour B. (2009), Polityka natury. Nauki wkraczaja do demokracji, tłum. A. Czarnacka, Wydawnictwo Krytyki Politycznej, Warszawa

Latour B. (2010), Splatając na nowo to, co społeczne. Wprowadzenie do Teorii Aktora-Sieci, tłum. A. Derra, K. Abriszewski, Wydawnictwo Universitas, Kraków

Lind M., Minichbauer R. (red. - 2009), Europejskie polityki kulturalne 2015. Raport ze scenariuszami przyszłości publicznego finansowania sztuki wspótczesnej. Wersja polska (red.), Wydawnictwo Fundacji Bęc Zmiana, Warszawa

McGuigan J. (1992), Cultural populism, Routledge, London-New York

McGuigan J. (2009), Cool Capitalism, Pluto Press, London-New York

McGuigan J. (2010), Cultural analysis, SAGE, Los Angeles-London-New Delhi-SingaporeWashington DC

Minichbauer R. (2011), Chanting the Creative Mantra: the Accelerating Economization of EU Cultural Policy, [w:] Critique of Creativity. Precarity, Subjectivity and Resistance in the Creative Industries, eds. G. Raunig, G. Ray, U. Wuggenig, MyFlyBooks, London

Mościcki P. (2008), Polityka teatru. Eseje o sztuce angażującej, Wydawnictwo Krytyki Politycznej, Warszawa

Pawłowski R. (2011), Kultura jako ekonomia i bunt, [w:]„Gazeta Wyborcza” - wydanie internetowe, tekst dostępny na stronie: http://wyborcza.pl/1,75475,10270341, Kultura_jako_ekonomia_i_bunt.html, [dostęp: 13.11.11]

Ranciére J. (2007a), Dzielenie postrzegalnego. Estetyka i polityka, Tłum. M. Kropiwnicki i J. Sowa, Korporacja ha!art, Kraków

Ranciére J. (2007b), Estetyka jako polityka, Tłum. J. Kutyła, P. Mościcki, Wydawnictwo Krytyki Politycznej, Warszawa

Raunig G., Ray G., Wuggenig U. (red. - 2011), Critique of Creativity. Precarity, Subjectivity and Resistance in the Creative Industries, eds. MyFlyBooks, London

Ray G. (2011), Industry and the Administration of Terror, [w:] Critique of Creativity. Precarity, Subjectivity and Resistance in the Creative Industries, eds. G. Raunig, G. Ray, U. Wuggenig, MyFlyBooks, London

Reinelt J.G., Roach J. R. (2007), Critical Theory and Performance, eds. J.G. Reinelt, J.R. Roach, The University of Michigan Press, Ann Arbor

Skórzyńska A. (2011), Kultura na czas kryzysu. Niedopowiedziany projekt polityczny, [w:] "Kultura współczesna. Teorie. Interpretacje. Praktyka”, nr 5(71), s. 165-185

van Osten M. (2011), Upredictable Outcomes/Unpredictable Outcasts, [w:] Critique of Creativity. Precarity, Subjectivity and Resistance in the Creative Industries, eds. G. Raunig, G. Ray, U. Wuggenig, MyFlyBooks, London

Vassilliu A. (2011), oficjalna inauguracja EKK, wypowiedź na podstawie własnej transkrypcji przemówień

Zdrojewski B. (2011), oficjalne zakończenie EKK, wypowiedź na podstawie własnej transkrypcji przemówień

Żmijewski A. (2007), Stosowane sztuki społeczne, tekst dostępny na stronie: http:// www.krytykapolityczna.pl/Nr-11-12/Stosowane-sztuki-spoleczne/menu-id27.html [dostęp: 13.11.11] 